\title{
Comparative analysis of regulatory framework related to private forest management in Slovenia and Federation of Bosnia and Herzegovina
}

\author{
Špela Pezdevšek Malovrh ${ }^{1 *}$, Mersudin Avdibegović ${ }^{2}$ \\ ${ }^{1}$ University of Ljubljana, Biotechnical faculty, Department od forestry and Renewable Forest \\ Resources, Večna pot 83, SI-1000 Ljubljana, Slovenia \\ ${ }^{2}$ University of Sarajevo, Faculty of Forestry, Zagrebačka 20, BA - 71000 Sarajevo, Bosnia and Herzegovina
}

\begin{abstract}
Forest policy and forest ownership patterns in Slovenia and the Federation of Bosnia and Herzegovina $(\mathrm{FBiH})$ have changed considerably in recent decades due to unprecedented scale of social, political and economic change. The distribution of ownership types varies between the countries - in Slovenia private forest ownership predominates (77\%), while in $\mathrm{FBiH}$ only about $20 \%$ of forest is private-owned. In both countries, private forest properties are small-scale and fragmented, which affects management opportunities and the scale at which policy interventions need to be made. This paper analyses the Slovenian and Central Bosnia Cantonal Law on Forests to assess how the regulatory framework affects private forest owners' (PFOs) rights, forest management and accelerates cooperation of PFOs. Both laws impose exclusive rights and responsibilities of PFOs, as well as limitation on how they can use their forests. In both countries, legislation contains detailed regulations for forest management activities and stipulate that mandatory forest management plans (FMPs) are an important tool that supports the implementation of sustainable forest management. In Slovenia, FMPs are prepared as common plans for all forests regardless the ownership, while in $\mathrm{FBiH}$ the Cantonal Law prescribes a separate forest management planning system for private forests. To improve the efficiency of private forest management, both laws support voluntary cooperation of PFOs. From the analysis, it can be concluded that there is a need for better harmonisation of public and private interests in relation to forest resources, especially in the case of $\mathrm{FBiH}$, and that the deregulation of property right is needed as well as that the level of involvement of PFOs in the forest policy making process is unsatisfactory, in most cases only formal.
\end{abstract}

Key words: private forests; Law on forests; property rights; forest management; private forest owners' cooperation; forest policy

Editor: Vilém Jarský

\section{Introduction}

Private forests are widespread in most European countries (more than $70 \%$ in Western Europe and less than $50 \%$ in Eastern Europe, but with an increasing trend) and consequently provide a variety of goods and services to society and economic benefits to private forest owners (hereafter PFOs) (Glück 2000; Fabra-Crespo \& RojasBriales 2015). Slovenia and Bosnia and Herzegovina are among European countries with the highest share of forests (UN 2011), therefore forests represent one of the crucial natural resource and plays a key role in the development and well-being of rural areas. Forest in Slovenia are mostly private-owned (77\%), while in the Federation of Bosnia and Herzegovina (hereafter FBiH), only about $20 \%$ of forest is private-owned (Wolfslehner \& Avdibegović 2015; ZGS 2020).
Structural changes over the last decades have stimulated an increasing diversity of PFOs (new urbanized or absentee PFOs), not only in Slovenian and FBiH, but also in Europe (Glück et al. 2011; Dayer et al. 2014; Côté et al. 2017; Ficko et al. 2019; Weiss et al. 2019). This is accompanied by a change in their interests, objectives, attitudes and demands towards forest ownership (Pezdevšek Malovrh 2010; Glück et al. 2011; Feliciano et al. 2017; Kumer 2017; Laakkonen et al. 2019; Weiss et al. 2019), which in turn influences the hierarchies of priorities in their forest management decisions (Ziegenspeck et al.2004) and challenges forest policy decision makers to reshape forest policy (Laakkonen et al. 2019).

Forest policy and management approaches in Slovenia and $\mathrm{FBiH}$ have changed considerably in the recent decades, particularly due to several socio-political

*Corresponding author. Špela Pezdevšek Malovrh, e-mail: spela.pezdevsek.malovrh@bf.uni-lj.si, phone: +003861320 3522 
changes. Following the political and economic transition in the early 1990s, Slovenia and FBiH have experienced changes in national political systems and institutional frameworks (Golubović 1995; Adam \& Makarovič 2001; Ferlin et al. 2010). In the forest sector, this led to the establishment of the public forest administration and the reorganization of private and state forest management, as well as the restitution and denationalization of parts of the state-owned forests (Winkler \& Medved 1994; Vuletić et al. 2010; Scriban et al. 2019). However, in addition to the positive developments, the changes have introduced new forest legislation, developed with little or no consideration or input from PFOs, and new management approaches that assume that PFOs have an active management interest in their forests (Golubović 1995; Adam \& Marković 2011; Ferlin et al. 2010).

Nowadays, forest policy decision makers in both countries face the problem of identifying the appropriate forest policy instruments and promoting policy objectives and acceptance among PFOs to meet emerging national and European policy objectives for forests such as biodiversity conservation, climate change, strengthening and enhancement bio-economy (Pezdevšek Malovrh et al. 2016; Pezdevšek Malovrh et al. 2019). Besides, a complex system of political and social interactions within and outside the forest sector is increasingly influencing forest policy.

The need for promoting forest policy to PFOs is particularly important given the relatively high share of private forest in Slovenian (ZGS 2020). In both countries, private forest properties are small-scaled and highly fragmented, with numerous owners and co-owners who have no connection to agriculture or forestry knowledge and practices and are not interested in the management of their property (Pezdevšek Malovrh 2010; Glück et al. 2011; Kumer \& Potočnik Slavič 2016; Kumer \& Štrumbelj 2017). This affects management opportunities (management levels in private forests are currently far below their productive potential) and the scale at which policy interventions need to be made. Therefore, forest policy makers in Slovenia and FBiH should shape the development of private forests by creating an operational environment and regulatory framework that is consistent with both, official forest policies and PFOs objectives.

To date, few comprehensive studies have been conducted in Slovenian and $\mathrm{FBiH}$ on the regulatory framework related to private forest ownership or management (Nonić et al. 2006; Marković et al. 2008; Ferlin et al.2010; Nikolić et al. 2011; Bouriaud et al. 2013; Nichiforel et al. 2018; Nichiforel et al. 2020). Most recent studies have focused on different aspects of private forest ownership, such as the PFOs management objectives (Ficko \& Bončina 2013; Kumer \& Potočnik Slavič 2016; Kumer 2017; Ficko 2019), the timber harvesting intensity in private forests and the potential mobilization of resources (Poje et al. 2016; Pezdevšek Malovrh et al. 2017; Stare et al. 2020), the PFOs types (Čabaravdić et al. 2011;
Pezdevšek Malovrh et al. 2015; Kumer \& Štrumbelj 2017) and PFOs cooperation (Avdibegović et al. 2010a; Avdibegović et al. 2010b; Glück et al. 2010; Pezdevšek Malovrh et al. 2010; Glück et al. 2011; Pezdevšek Malovrh et al. 2011; Leban 2014; Pezdevšek Malovrh \& Laktić 2017; Černač \& Pezdevšek Malovrh 2020; Plevnik $\&$ Pezdevšek Malovrh 2021).

Although some studies have started to explore the issue of private forests in Slovenian and $\mathrm{FBiH}$, they do not examine in detail the aspect of the regulatory framework. To fill that gap, this study aims to provide a structured comparative analysis in two case countries, Slovenian and $\mathrm{FBiH}$ in order to understand how regulatory framework affects PFOs' property rights, forest management aspects and accelerates PFOs' cooperation. The two case countries were selected because they have similar natural conditions for forest management and the same historical socio-political background (former socialist countries).

On the other hand, these countries show markedly differences since the early 1990s in terms of the economic wealth and quality of governance. Thus, examination and comparison of regulatory framework in the selected countries can provide important information for the future design of forest policy and is likely to be relevant for forest policy decision-makers, institutions responsible for forest management and planning, and PFOs to enhance the quality of future operational forest management practice.

\section{Materials and methods}

In this study, the basic regulatory framework for the forest sector of Slovenia and FBiH was analysed from the perspective of the private forest issues. In both countries, forest regulations that may affect private forest management and PFOs scope of decision making, includes forest programs and strategies, laws, rules and decrees. While private forest management issues are mainly defined in the text of Forest Laws, in our analysis only the rule of Forest Law (de jure situation) was considered and other sub-regulations nor perceptions of PFOs' on practical implementation (defacto situation) were not considered.

After Slovenia's independence, the first Forest Law was adopted in 1993. Since then, several amendments to the law have been made (Official Gazette of the Republic of Slovenia, No. 30/93, 56/99, 67/02, 110/02, 115/06, 110/07, 106/10, 63/13, 101/13, 17/14, 22/14, 24/15, 9/16, 77/16). In Bosnia and Herzegovina, forest policy and legislation are decentralized and designed by the entities (Republic of Srpska and FBiH). Due to the complicated administrative structure of the state and specific constitutional solutions, there is neither a common legal framework for forest management nor a consistent forest policy at the state level. Therefore, management competencies regarding forest resources in Bosnia and Herzegovina are concentrated at the entity level. Each of 
these two entities has its own Forest Law, which differ from each other. In $\mathrm{FBiH}$ the federal Forest Law from 2002 was declared invalid in 2009 - for more details see Wolfslehner and Avdibegović (2015). Although several drafts of a new Forest Law have been proposed by different institutions, there is no political agreement on it so far. Nevertheless, forest sector in $\mathrm{FBiH}$ cannot be considered legally unregulated. The Government of $\mathrm{FBiH}$ shares (and delegates) some of its responsibilities with the Cantonal administrations. Since both (the Government of $\mathrm{FBiH}$ and the Cantons) have the right to determine forest policy, almost in all the Cantons of $\mathrm{FBiH}$ (except Herzegovina-Neretva Canton) have adopted Cantonal Forest Laws which are more or less similar in content. The analysed Law on Forests of Central Bosnian Canton (hereafter: CBC Forest Law) was chosen in our study because it represents well the conditions in $\mathrm{FBiH}$ related to private forest management and due to the fact that only in this Canton there is an active Cantonal association of PFOs in the whole FBiH. Having this in mind, it was interesting to see to what extent the CBC Forest Law relates to the issue of private forest and its related management.

As the aim of this paper was to make a comparative analysis of Slovenian and FBiH Forest Law in order to identify similarities and differences in relation to the regulation of private forests, the following three substantive elements of the legal provision, such as "forest property rights", "forest management planning system" and "cooperation of PFOs" were analysed in detail. In addition, the analysis focuses only on productive forest, so legal provisions referring to protected forests are not included in the analysis.

For the analysis of forest property rights, the framework of Schlager and Ostrom (1992) was used following the Property rights index in forestry (hereafter PRIF) developed by Nichiforel et al. (2018). The PRIF analysed five categories of property rights that represent the bundle of rights associated with forest attributes that have value to the PFO. These property rights categories are: 1) access rights (the right of owners to access their forest or forest land), 2) withdrawal rights (the right to harvest or remove timber, firewood and non-wood forest products-NWFPs), 3) management rights (the right to plan forest activities and transform the forest), 4) exclusion rights (legal requirements to prevent access and harvesting of timber and collecting NWFPs by external users), 5) alienation rights (the right to sell forest land and timber).

\section{Results}

Based on the existing regulatory framework in Slovenia and $\mathrm{CBC}$ in $\mathrm{FBiH}$, it can be concluded that the provisions of forest legislation apply to all forests regardless the ownership type, nevertheless there are some differences between public and private forests in the case of $\mathrm{FBiH}$.

\subsection{Definition of private forest ownership}

In the "General provisions" chapter, both laws contain definitions of certain terms related to private forest ownership. CBC Forest Law defines the term "private forest owners'" as a legal and/or natural person who has legally acquired the right to the ownership of the forest or forest land, as evidenced by the Land Registry (Article 3). The law also stipulates in "Chapter Management of forest and forest land" that "private forest" means all forests and forest land for which a natural or legal person has an evidence issued by Land Registry as proof of ownership (Article 34). In the Forest Law of the Republic of Slovenia, the article defining certain terms does not contain a definition for the term "private forest owner", but defines a "forest owner", either as a "natural or legal person" (Article 4). The law also does not define the term "private forest". With the exception of the term "private forest owner or forest owner" analysed laws do not mention any other terms that would further specify the issue of management and administration of private forests (e.g. PFOs' associations, a representative of PFOs, PFOs cooperation, professional services for PFOs, an advisory function, etc.).

\subsection{Forest property rights}

The CBC Forest Law prescribes that forests and forest lands (regardless of ownership) are natural resources and goods of general interest whose value is manifested through their ecological, social and economic functions, and as such enjoy the special care and protection of the Canton and local self-government units (Article 2). The Slovenian Forest Law also stipulates that forests are a source of natural wealth and, according to the Environmental Protection Law, are a public good (Article 3), the value of which is manifested through the ecological, social, and economic functions of the forests (Article 3 ). It follows that private forests, although owned by PFOs (in most cases natural persons), are private property over which PFOs have the inalienable right to manage, use and transfer ownership (sell), but as such are nonetheless also of public interest, as reflected in the generally useful functions and services of forest ecosystems. For this reason, forest management, silviculture, the protection and use of forests as a natural resource, and the activities of the public forest administration are regulated in Forest Law, even though this limits to some extent the full freedom of PFOs to manage their forests as they see fit. This is also evident in the both laws as specific rights, duties, obligations and restrictions on private ownership are prescribed in relation to the resource. In both laws, the duties and obligations of PFOs are largely aligned, especially when it comes to implementation of forest protection measures (from diseases, harmful organisms and other damages), free access to the forest and management in accordance with regulations 
and FMPs. In terms of restrictions and prohibitions, the PFOs in Slovenia have fewer prescribed restrictions and prohibitions compared to the PFOs in $\mathrm{FBiH}$. According to the Slovenian Forest Law the following is prohibited: any action in the forest that reduces the growth of stands, habitat capacity, stability or sustainability of the forest or endangers its functions, existence or purpose (Article 18); felling without an administrative order issued by the Slovenian Forest Service (Article 17); placing on the market forest wood assortments until issuance of the required transport document for felled timber has been issued (Article 17b); clear cutting (Article 22); use of chemical substances (Article 31); grazing (Article 32); open fires and burning of grassland (Article 33) and the use of forest roads for purposes unrelated to forest management (Article 37). The situation is similar in the CBC Forest Law, where the following is prohibited: grazing, acorns, buds, pruning of branches and leaves within the forest (Article 23); clear cutting and forest devastation (Article 13); placing on the market timber and NWFPs until the dispatch statement has been issued (Article 16); open fires (Article 21); construction and operation of factories and other facilities using open fires at a distance of less than 300 meters from the forest boundary (Article 21); use of chemical substances, disposal of waste, garbage or pollutants (Article 22); felling, uprooting or any damage to endangered trees and shrubs species (Article 27); deforestation of forests (Article 46); any unauthorized occupation of state forests and forest lands (Article 32).

The property right of PFOs are analysed in more detail in the subsections, based on the PRIF developed by Nichiforel et al. (2018), which follows the framework of Schlager and Ostrom (1992), as described in the Material and Method section. Summary results of the analysis are presented in Table 1 in Appendix.

\subsubsection{Access rights}

The access right to the forest was assessed in terms of the freedom of PFOs to freely enter their own forest (Nichiforel et al. 2018) and to enjoy non-subtractive benefits (Nichiforel\&Schanz 2011). In the analysed laws, this right is fully granted to PFOs. Some restrictions may apply in both laws for health and safety reasons, fires prevention or policy and military purposes. Under both laws, the PFOs have the right to compensation for its restricted forest use, property rights, or increased management costs. In addition, according to Slovenia Forest Law in this case the PFOs has the right to apply for appropriate tax relief or can demand that the proclaimer (the Republic of Slovenia or the local government) purchase this forest. In both laws, the fee is paid by the person on whose request the proclamation was made (Article 46 of Slovenian Forest Law and Article 17 of CBC Forest Law).

\subsubsection{Withdrawal rights}

The withdrawal right concerns the state's involvement in determining or supervising PFOs with respect to what or how much they are permitted to harvest from their forest (Nichiforel et al. 2018), which includes PFOs' freedom to determine the amount of timber to be harvested from the property, approval that is required by PFOs for timber harvesting, PFOs' freedom to perform harvesting and PFOs' freedom with respect to NWFP collection.

Based on Forest Law, PFOs in both jurisdictions cannot decide on the amount of timber to be harvested on their forest lands, as this is determined by the provisions of a mandatory FMPs. According to the CBC Forest Law it is not allowed to exceed the total volume of felling by tree species and management classes provided for in FMPs for the management period (Article 5). According to Slovenian Forest Law, FMPs specify the conditions for harmonized use of forests and activities in forests and forest areas, the required level of silviculture and protection measures, the maximum extent of their use, and the conditions for wildlife management (Article 9).

In both analysed countries, the Forest Law requires that PFOs inform authorities and obtain their permission before harvesting trees. In the case of the CBCForest Law (Article 8), it is required that prior to felling (regular or sanitary ones) in private forests, the Cantonal Administration for Forestry reports the felling to the relevant forest inspector and to the local communities in whose area felling takes place. This report contains a large amount of data, including a permission for felling and the conditions under which the felling can be carried out. In the Slovenian Forest Law, PFOs need to contact Slovenian Forest Service prior to felling (regular or sanitary one), which is a public forest service that carries out professional activities in all forests, regardless of ownership (Article 50). Article 17 of the Law prescribes that Slovenian Forest Service selects trees for possible felling together with the PFOs after prior consultation and issue an administrative instruction to the PFOs, which also contains the condition under which felling can be carried out. The possible felling is the maximum quantity of trees in gross $\mathrm{m}^{3}$ that the PFO may fell during the validity of the decision. According to Article 17a of the Law, the decision is usually issued for several years, but not longer than 5 years. In this regard, PFOs in both countries have to inform the authorities and ask for a permit in any situation.

Regarding the freedom of PFOs to perform the harvesting of trees, it is noted that PFOs have the right to harvest the trees by themselves only in Slovenia. The Slovenian Forest Law stipulated that PFOs may perform forest activities and may be assisted by their legal heirs, spouses and other natural persons in the form of mutual assistance. Forest activities may also be performed by natural or legal persons registered to perform such works, meeting the requirements for professional qualifications (Article 9). According to the CBC Forest Law 
(Article 12), forest activities (whether related to public or private forests) may be performed only by persons qualified or trained to perform the relevant work. Whereby the legal person registered to perform forest activities must ensure the technical and professional training of employees. This prevents PFOs to perform harvesting by themselves unless they fulfil provisions of Article 12 and neglects the traditional skills of rural population, often well developed in Bosnia and Herzegovina. Besides, this article is in contradictory with Article 10 which stipulate that PFOs are obliged to perform the activities of biological reproduction of the forests (for example afforestation) at least to the extent provided in the FMP.

For NWFPs there are fewer legal requirements compared to the timber withdrawal. Collection rights for private use of NWFP are granted to PFOs in both countries, but there are maximum quantity limits. In the case of Slovenian, the quantity limits are regulated in Regulations on the Protection of Forests (i.e. $2 \mathrm{~kg}$ of mushrooms per person per day, without differentiating whether the picker is $\mathrm{PFO}$ or visitor), while they are regulated in the $\mathrm{FBiH}$ in Cantonal Law (3 kg of NWFP for private use; Article 30). According to the CBC Forest Law (Article 25), PFOs may cultivate and use NWFP or allow other legal and natural persons to use these products under professional supervision, to the extent and in the places specifies in the FMPs. Similarly, in Slovenian Forest Law, the use of forest functions is allowed to PFOs and natural persons. This means that any natural person may collect mushrooms, forests fruits and other plants growing in forest, pick herbal plants and parts thereof, and perform beekeeping in the forest (Article 3 and Article 5). The Forest Law also states that in forests where collecting of NWFP would endanger a plant or animal species or forest function, collecting is restricted or prohibited. Restriction of collection to a certain type, quantity, manner, area and time or prohibition of collection is ordered by the Minister responsible for forestry. Commercial use of NWFP is not regulated in Slovenian Forest Law, while CBC Forest Law states it is prohibited to collect NWFP weighing more than $3 \mathrm{~kg}$, except for commercial purposes for which PFO approval is required (Article 30).

\subsubsection{Management rights}

The regulation of management rights concerns the legal rights of PFOs for management planning and implementation of forest management (Nichiforel et al. 2018), which includes the obligation of PFOs to have a FMPs, the freedom of PFOs to choose forest management objectives and the freedom of PFOs to select the trees to harvest.

FMPs are mandatory in both countries, regardless of the size of the private forest property and regardless of the forestry work intended by the PFOs. The analysed laws state that FMPs are prepared for a period of 10 years for all forests to ensure the sustainability of forest management. Article 5 of the CBC Forest Law defines that FMPs, under which forests in a specific region are managed, shall be prepared for state forests within the boundaries of a forest management region and for private forests within one local community. As a result, two parallel management and planning systems have emerged in the CBC. The Forest Law also states that FMPs are prepared for a period of 10 years and their provisions are binding.

Article 6 of the Forest Law of Slovenia stated that the National Forest Programme and FMPs are the basis for forest management (Article 6), which are prepared for a period of 10 years (Article 9). According to the law, FMPs are prepared as common plans for all forests regardless of ownership, considering the specifics of individual areas. (Article 9).

In both countries, preparation of FMPs for private forests are financed by public authorities, in Slovenia by the State and in $\mathrm{FBiH}$ by Canton (Article 57 of the $\mathrm{CBC}$ Law on Forest and Article 48 of Slovenian Law on Forest). Consequently, silvicultural practices and operations implemented in private forests are still mainly subject to state control, especially in $\mathrm{FBiH}$, where the provisions of FMPs are binding (Article 5).

Significant differences were found between the analysed laws with regard to the participation of the PFOs in the development of FMPs. These differences mainly relate to the level of detail of the provisions prescribing this issue and to the freedom of PFOs in choosing forest management objectives. Thus, the CBC Law on Forests does not provide for PFOs to participate in the development of FMPs related to their forest. The opposite is the case in Slovenia, where Forest Law prescribes the involvement of PFOs and the public concerned in the preparation of FMPs - participation in the process of preparing FMPs (Article 14). This article requires that at the beginning of the preparation of a FMPs, the Slovenian Forest Service (public forest administration) shall appropriately notify the PFOs and the concerned public, who may make their suggestions during the preparation of the draft FMPs. In addition, the law requires that the Minister responsible for forestry shall, by order, direct that the draft FMPs be made available for public display for 14 days and a public hearing be held after the public display. Appropriate notice of the commencement and duration of the public display and public hearing shall be given to PFOs and the concerned public. Notice of the public display and public hearing shall also be posted on the website of the Ministry responsible for forestry. Upon competition of the public display and hearing, the regional unit council of Slovenian Forest Service shall consider and comment on the comments and proposals. On this basis, the Slovenian Forest Service prepares a proposal for FMPs. From this it can be seen that PFOs can contribute their management objectives in the forest management planning process, but they do not have the freedom of decision. 
When it comes to the freedom of PFOs to select trees for harvesting, there are differences in the analysed Forest Laws. In both countries, the trees can only be felled after they have been selected, marked and recorded in accordance with the forest FMPs (Silvicultural plan in Slovenian and FMPs in $\mathrm{FBiH}$ ). According to the CBC Forest Law, the selection of trees for harvesting in private forest is done only if the PFO can prove the ownership of the forests. In the case of Slovenia, the law (Article 17a) stipulates that PFOs are responsible for the indicated boundaries of their forests, so they do no need to prove the ownership. Both laws require that PFOs inform authorities and obtain their permission before harvesting trees (see chapter 3.2.2). In addition, Article 34 of the CBC Forest Law explicitly states that PFOs manage their own forests and that the performance of professional activities (marking trees for felling, construction projecting, receiving and measuring timber, issuing a dispatch note, silvicultural works, and keeping records of works performed) is carried out on a contractual basis and for a fee by the Cantonal Administration for Forests or a legal entity registered to perform forestry services. The Forest Law provides that the mentioned fee does not exceed $10 \%$ of the price of timber on a stump, according to the price list of public forest user (Cantonal forest management company). According to the provisions of the Slovenian Forest Act (Article 3), the selection of trees for felling is a part of silvicultural activities, whereby individual trees or groups of trees are marked for felling in accordance with the condition of the forest ecosystem, objectives, intensity of management and needs of PFOs. In Slovenia, professional activities (marking trees for felling, issuing documents for placing forest wood assortments on the market, monitoring the health status of forests, preparing and drawing up planning documents and providing professional advisory services to PFOs) are carried out in all forests, regardless of ownership, by the Slovenia Forest Service as the public forest administration (Article 50). Its services are free of charge for the PFOs as its activities are financed from the budget (Article 48).

\subsubsection{Exclusion rights}

The regulation of exclusion rights concerns the legal ability of PFOs to allow or prevent the general public or other public forest user categories from entering and benefiting from the forest resource (Nichiforel et al. 2018), which includes the freedom of PFOs to restrict the public access to their property, the freedom of PFOs to restrict the collection of NWFPs on their property, and the freedom of PFOs to decide who may hunt on their property.

Free access in private forest cannot be restricted by PFOs in either of the analysed Forest Laws because it is everyone's right. Both laws require that PFOs must provide free access to their forests, where this means free movement or walking or other forms of enjoyment through the forest or forest land, without material gain (in the case of CBC Forest Law; Article 30) or with the exception of profit-making activities related to tourism or recreation (Slovenian Forest Law; Article 6). Both laws require that free movement is at one's own risk and in accordance with the forest regulation or the FMPs (only prescribed in $\mathrm{CBC}$ Forest Law). In addition, the $\mathrm{CBC}$ Forest Law prescribes that free access to the forest may be restricted in protected forests or part of the forest exposed to negative anthropogenic and other influences (Article 30).

Regarding the collection of NWFP, both Forest Laws stipulate that PFOs must allow recreational collection of NWFP in their forest in accordance with the regulations (Article 5 of the Slovenian Forest Law and Article 30 of the CBC Forest Law); however maximum quantity limits apply (see chapter 3.2.2). In the case of Slovenia, the collection of NWFP in forests may be restricted or prohibited if the collection of NWFP would endanger a plant or animal species or the forest function (Article 25). Restriction of collection to a certain type, quantity, manner, area and time or prohibition of collection is ordered by the Minister responsible for forestry. The same article stipulates that in forests where PFOs cultivate fruit trees, other users may be prohibited from collecting these fruits. The prohibition, is prescribed by the competent body of the local self-government unit on the proposal of the PFOs (Article 25).

With regard to hunting activates, Forest Law in Slovenia, prescribes that PFOs must allow beekeeping and hunting according to the regulations (Article 5), which means that PFOs has to accept hunting activities that take place in their forest and are not compensated for this. In the case of CBC Forest Law, camping, hunting and beekeeping are prohibited without the permission of PFOs (Article 30).

\subsubsection{Alienation rights}

The alienation rights regime concerns the right of PFOs' to sell forest land and timber (Nichiforel et al. 2018), which includes the freedom of PFOs to decide to whom they want to sell the forest land and the freedom of PFOs to decide to whom they want to sell the timber.

According to the analysed Forest Laws, PFOs have the right to sell forest land but in Slovenia it is altered by pre-emption right in favour of the state/local communities and neighbouring owners. The pre-emption right is not prescribed by CBC Forest Law when it comes to private forest trade. Article 47 of Slovenian Forest Law defines prohibitions and orders in the field of forest trade. This article stipulates the pre-emption rights of the Republic of Slovenia in the purchase of protective forests with a highlighted ecological function; the local community in the area where the forests with a protective, recreational, tourist, educational, defensive or aesthetic 
function, are located as well as forests declared as natural attractions, and the owner of the land adjacent to the forest for sale. If the owner of the land adjacent to the forest to be sold does not exercise the right of priority, the right shall belong to the other owner whose forest is closest to the forest to be sold.

In addition, Slovenian Forest Law also contains a defragmentation policy that restricts the division of forest land into smaller parcels and regulates sales to limit further fragmentation. Forest Law states that forest parcels smaller than five hectares can be divided in cases where the spatial planning law do not specify forest as intended use, when it comes to the needs for the construction of public infrastructure, when it is co-owned by the Republic of Slovenia or the local community (Article 47).

The right of PFOs to sell timber is altered in both laws by a specific procedure. Slovenian Forest Law requires in Article 17b that forest wood assortments loaded on a vehicle or transported by road must be accompanied by an accounting document to control the traceability of movement of forest wood assortments and to perform supervision in accordance with the law. Such a document is not required for forest wood assortments from private forests that are loaded onto a vehicle or transported by road if their total quantity does not exceed $10 \mathrm{~m}^{3}$ and if they are intended for personal use, as well as in the case when forest wood assortments are the subject of a sale or gift between two natural persons. In this case, PFOs must have a permit for timber harvesting original or copy, issued by Slovenian Forest Service, from loading to unloading of the assortments.

CBC Forest Law states in Article 16 that timber, trees parts and branches cut in and from the forest may not be removed from the stump until they have been marked, stamped and registered with a forestry hammer. It is prohibited to place them on the market until the formal dispatch note (bill of lading) has been issued. Stamping, grading, measuring, registering and issuing of dispatch statement for timber from private forests is carried out by the cantonal administration or a legal entity registered to carry out professional activities in private forests.

In both laws analysed, there are no restrictions imposed on PFOs in setting the price of forest land or the price of timber nor the selling method for timber.

\subsection{Forest management planning system}

Article 3, "Definitions of Terms", of the CBC Forest Law and the Slovenian Forest Law defines general terms related to the forest management system, such as forest management regions and forest management units. However, in Slovenian Forest Law these terms refer to all forests, regardless of ownership, whereas in the CBC Forest Law they refer mainly to public forests (see paragraph below). As a result, two parallel forest management and planning systems exist in the $\mathrm{CBC}$, one for state forests and another for private forests, which is reflected in the significant differences in the state of public and private forests, i.e. stand type (high and low forests), growing stock and the increment volume of wood, and the overall health of forest stands (Wolfslehner\&Avdibegović 2015).

Both laws deal with issues concerning forest management planning issues in separate chapters. Article 4 of the CBC Law starts with the provision that forest management regions have been established to ensure rational and sustainable management of state forests and forest lands. The Forest Law of Slovenia stipulates that in order to ensure sustainability of forests and to plan, manage and monitor the development of forests and forest lands, regardless of their ownership, forest management regions shall be established as integral territorial ecosystem units. The intention to advocate sustainable management of all forests regardless of ownership is evident in the Slovenian law, while in the CBC law this applies only to public (state-owned) forests, which put private forests to a subordinate position. A strict interpretation of the legal provisions of the $\mathrm{CBC}$ Forest Law also indicates that private forests are not included in forest management regions (although they do not differ in terms of tree species, soil substrate and climate conditions to which they are exposed), but are managed under a separate forest management planning system. Both laws define that FMPs are medium-term planning documentations prepared for the period of 10 years (Article 15 in Slovenian Forest Law and Article 5 in CBC Forest Law). Article 5 of the CBC Law defines that FMPs, according to which forests in a specific region are managed, are prepared for state forests within the boundaries of one forest management region and for private forests for all forests located within one local community. Contrary in Slovenia FMPs are drawn up as joint plans for all forests regardless of ownership, taking into the account the particularities of individual areas (Article 9).

Based on Forest Law, in Slovenia the content of FMPs is public, which means that PFOs could have access to FMPs and be aware of their content. Moreover, the law requires that FMPs must be permanently stores after the expiry of their validity (Articles 8). The situation is different in CBC Forest Law, where the law requires that the Canton Government is the owner of all data and documents in electronic and/or other form generated in the preparation of FMPs for all forests. Without disputing the need to treat private forests as a public good of general interest (which is prescribed in this Law), such a definition of "data ownership" is contrary to key principles of "good forest governance", such as participation and transparency. Some form of ownership of private FMPs, both in a formal sense and in their essence, should undoubtedly be granted to PFOs.

In addition, the analysed laws also prescribe the procedure of how FMPs are adopted and who is responsible for their adoption. The Slovenian Forest Law prescribes 
the involvement of PFOs and the public in the preparation of FMPs and after the draft has been prepared (see chapter 3.2.3). On this basis, the Slovenian Forest Service prepares a FMPs, which much receive the consent of the Minister responsible for the environment, spatial planning and water and the Minister responsible for nature conservation (in case of regional FMPs), or the opinion of the organisation responsible for nature protection and the opinions of local communities in the area where the management unit is located (in case of FMPs for a forest management unit). Thereafter, the Slovenian Forest Service submits the FMPs to the Ministry responsible for forestry for approval. A regional FMPs is adopted by the Government of the Republic of Slovenia, while a FMP for a forest management unit is adopted by the Minister responsible for forestry.

In $\mathrm{FBiH}$, the $\mathrm{CBC}$ Forest Law provides that FMPs for state forests are to be adopted by a Cantonal forest management company, with prior consent of the competent Ministry and the opinion of the local community. For private forests, FMPs are adopted by the relevant Cantonal Ministry. A systematic view of the forest management planning system governance is proposed in the Table 1 .

\subsection{Private forest owner's cooperation}

When it comes to PFOs cooperation, there are significant differences between the analysed laws (Table 2). Voluntary cooperation of PFOs is provided in both Forest Laws, but the differences in the laws relate to the level of detail of the provision regulating the cooperation exists. For example, the CBC Forest Law (Article 34) only stipulates that PFOs may establish a private forest owners' asso- ciation (hereafter PFOA) for the purpose of exercising their property rights, while Slovenian Forest Law contains a separate chapter on "Cooperation" that refers to cooperation among PFOs. According to Slovenian Forest Law (Article 74a), voluntary cooperation among PFOs in PFOA is encouraged to increase the efficiency of forest management and the marketing of forest products and forest biomass. In addition, the Forest Law promotes cooperation among PFOs in various organisational forms. It is specified that natural persons (PFOs) may establish machinery rings for more efficient use of forest machinery and equipment, work force and other production capacities, along the line of the regulation for agriculture. However, the law stipulates that PFOAs, whose purpose of establishment and operation goes beyond the realisation of the interests of their members and which act in the public interest in terms of forestry may be granted the status of acting in the public interest by the Minister responsible for forestry. Acting in the public interest in the field of forestry means, above all, that the PFOAs develop various types of programmes with different content, which serve to popularise forests and forestry (Article 47b). The law also provides financial incentives for the initial activities of PFOAs (Article 48).

\section{Discussion}

In the last three decades, forest sector in Slovenia and $\mathrm{FBiH}$ has faced many substantial changes, such as changes in institutional set-up, the emerging new structure of PFOs, which is the result of changes in lifestyle, attitudes and behaviour of PFOs (Glück et al. 2011; Kumer 2017), and the increased political attention to

Table 1. Summary results of forest management planning system governance in FBiH and Slovenia.

\begin{tabular}{lll}
\hline Forest management planning in private forests & \multicolumn{1}{c}{ FBiH } & \multicolumn{1}{c}{ Slovenia } \\
\cline { 2 - 3 } Is the FMP required for the private forest? & $\begin{array}{l}\text { Yes, FMPs are compulsory and are prepared for private } \\
\text { forests for all forests located within one local commu- } \\
\text { nity. The FMPs applies for a period of 10 years }\end{array}$ & $\begin{array}{l}\text { Yes, FMP are compulsory and drawn up as joint plans } \\
\text { for all forests regardless of ownership. The FMPs ap- } \\
\text { plies for a period of 10 years }\end{array}$ \\
\hline Are FMPs publicly available? & $\begin{array}{l}\text { No, the Canton Government is the owner of all data and } \\
\text { documents }\end{array}$ & Yes, the content of FMPs is public \\
\hline $\begin{array}{l}\text { What is the degree in which the PFOs has the right to } \\
\text { participate in forest management planning? }\end{array}$ & $\begin{array}{l}\text { No contribution from the PFOs side in the planning } \\
\text { process }\end{array}$ & $\begin{array}{l}\text { The PFOs has the right to participate. PFOs opinions } \\
\text { should be recorded within the planning process, but not } \\
\text { necessarily included in FMP }\end{array}$ \\
\hline $\begin{array}{l}\text { Who is responsible for the preparation and adoption } \\
\text { of FMPs? }\end{array}$ & $\begin{array}{l}\text { The public forest administration at the cantonal level } \\
\text { (Cantonal forest office) is responsible for the prepara- } \\
\text { tion of FMPs for private forests. FMPs for private forests } \\
\text { are adopted by relevant Cantonal ministry }\end{array}$ & $\begin{array}{l}\text { The Slovenian Forest Service (public forestry service) } \\
\text { is responsible for the preparation of FMPs. Ministry } \\
\text { management unit, while the Government adopts the } \\
\text { regional FMPs }\end{array}$ \\
\hline
\end{tabular}

Table 2. Summary results of PFOs cooperation in FBiH and Slovenia.

\begin{tabular}{lll}
\hline PFOs' cooperation & \multicolumn{1}{c}{ FBiH } & \multicolumn{1}{c}{ Sountry } \\
\cline { 2 - 3 } & \multicolumn{1}{c}{ Ses, the PFOs' organization is predicted } & Yes, the PFOs' organization is predicted \\
\hline Is PFOs' organization predicted? & Private forest owner's association & Private forest owner's association, machinery ring \\
\hline $\begin{array}{l}\text { Wh membership in PFOs' organizations mandatory or } \\
\text { voluntary }\end{array}$ & Voluntary & Voluntary \\
\hline What are the purposes of PFOs' organization? & To exercising PFOs property rights & $\begin{array}{l}\text { To increase the efficiency of private forest management } \\
\text { and the marketing of forest products and forest biomass. }\end{array}$ \\
\hline Is a financial support provided by the Government? & No & $\begin{array}{l}\text { Yes, financial incentives for the initial activities are } \\
\text { provided }\end{array}$ \\
\hline
\end{tabular}


sustainable forest management resulting from emerging political agendas of EU sectoral policies (Wolfslehner \& Avdibegović 2015; Leban et al. 2016; Pezdevšek Malovrh et al. 2019). As a result, a complex system of social and political interactions within and outside the forest sector increasingly influences forest policy all around the Europe (Winkel et al. 2011; Winkel 2017; Nichiforel et al. 2018; Section 2020), which is also reflected in Slovenia and $\mathrm{FBiH}$, where country-specific regulatory framework has been developed that govern PFOs decision making freedom, forest management and PFOs cooperation.

\subsection{Socio-political context as the main factor for highly regulated regulatory framework}

Common features of the valid Forest Laws in Slovenia and $\mathrm{FBiH}$ are that they recognise the multifunctional role of forests and promote sustainable use and management of forests, but on the other hand have a very rigid regulatory framework governing private forests, which highly restricts property rights in both countries and has impact on the entrepreneurial activities of PFOs. In a Europewide comparative study of the impact of the regulatory framework on property rights distribution in forestry, Slovenian PFOs achieved 44,9 degrees of freedom ${ }^{1)}$, while in FBiH PFOs achieved 42,6 degree of freedom, compared to PFOs from the Netherlands, which achived the maximum degree of freedom $(84,7)$ (Nichiforel et al. 2018). This means that in Slovenia and FBiH, along with other Balkan countries and Eastern European countries (Bouriaud et al. 2013; Nichiforel et al. 2018), the regulatory framework that governs private forests is much stricter, particularly for harvesting and management rights, compared to countries from Central, Westeren and North Europe, mainly due to the socialist political background (Nichiforel et al. 2018). Also, our study showed that each jurisdiction in the analysis has a different approach to regulate the interplay between the private and public use of forest, which might be a result of a different share of private forest in analysed countries. But those differences are minor, which was also confirmed by Nichiforel et al. (2018), where it was concluded that in former socialist countries the area of private property does not significantly correlate with PRIF, thus countries with a higher share of private forest ownership do not necessarily have higher degrees of freedom.

\subsection{Strong adherence to governmental regulation restricts private forest owners' property rights}

The comparative analysis of PFOs property rights shows a variation in property right between Slovenia and $\mathrm{FBiH}$. Differences related to access, exclusion and alienation rights are really minor as in both laws access right is fully granted to PFOs, but more restrictions apply in case of FBiH. Moreover, public access into private forest for recreational purposes and collection of NWFP cannot be restricted, with some exceptions in specific situation. When it comes to the alienation rights, PFOs have the right to sell the forest land and timber in both countries, where in Slovenia the right to sell forest land is altered by a pre-emption right. The similar finding was found in Nichiforel et al. (2018), where access and alienation rights were very rarely restricted in European jurisdictions and only in exceptional cases.

The combination of withdrawal and management rights makes a significant difference across analysed countries. The results are in line with Nichiforel et al. (2018), where combination of withdrawal, management and exclusion rights makes a very diverselandscapeacross the European jurisdictions. The withdrawal rights related to the decision making regarding the amount of timber to be harvested only slightly differentiate between Slovenia and $\mathrm{FBiH}$, as laws require that all forests regardless ownership had to be covered by FMPs, which specify the amount of timber to be harvested, but the provisions are binding only in $\mathrm{FBiH}$. Therefore, in Slovenia and $\mathrm{FBiH}$, the provision of the FMP regulates the timber harvesting rights. Moreover, the analysis shows that the withdrawal rights on timber, recognised in the FMPs, are in reality strongly restricted from an economic viewpoint as PFOs hold only a residual control over withdrawal rights, due to the fact that the amount of timber to be harvested cannot be decided by PFOs. As stated in Bouriaud et al. (2013), the PFOs can only accept or reject the amount of timber entirely specified in a technocratic-lead process. This is limiting the PFOs' ability to benefit from their forest or to harvest as reaction to the market opportunities or to some extend to the cash flow needed. Moreover, additional administrative procedures apply in both countries, such as harvesting permit and compulsory recording of the timber to be harvested, marking of trees and procurement of the transportation documents issued by authorities. The results are in line with Bouriaud et al. (2013), where in most of Central and East European countries

\footnotetext{
1) The scale for assessing the rigour of the laws related to PFOs property rights ranged from 0 - meaning "the right is fully restricted" to 100 - meaning "no legal restrictions are imposed", with intermediary values being possible.
} 
additional administrative procedures apply. The level of bureaucracy required to issue the harvesting permit is higher in FBiH compared to Slovenia. In addition, in $\mathrm{FBiH}$, the services of tree marking for felling has to be paid by PFOs as it is carried out by the Cantonal public forest administration or a legal entity registered to perform forestry services on a contractural basis, which is also the case in Eastern European countries, where the service of tree marking is mandatory and therefore PFOs has to pay for it (Bouriaud et al. 2013).

Freedom of PFOs to perform the harvesting activities strongly differentiates between analysed countries. PFOs in Slovenia may perform forest activities by themselves and may be assisted by their legal heirs, partners and other natural persons in the form of mutual assistance or can be performed by natural or legal persons registered to perform such works, meeting the requirements for professional qualifications. The similar finding was found in Nichiforel et al. (2018), where PFOs has in $78 \%$ European jurisdictions right to harvest the trees by themselves.

On the contrary, harvesting activities in $\mathrm{FBiH}$ may be performed only by persons qualified or trained to perform the relevant work at the PFOs' cost, which is according to Nichiforel et al. (2018) very rarely restricted in European jurisdictions. In practise in $\mathrm{FBiH}$, the performance of the works in private forests is contrary to the law, as works in private forests are mostly performed by the PFOs with the help of other natural persons (e.g. family members, neighbours, relatives, friends). The performance of works in private forests is very rarely entrusted to legal persons registered for the provision of forestry services. Exceptions may arise in "selling stump wood" to other natural or legal persons, but in most cases these services are not performed by legal persons registered to provide forestry services and meeting the required technical and professional standards. This tacitly violates the law, which did not adequately recognise the predominant use of private forests (usually small quantities of firewood and roundwood for the personal needs).

\subsection{Forest management plans as a "stick" forest policy instrument}

The main source of variation among the analysed laws is related to the forest management planning systems, PFOs degree of freedom to formulate the management objectives and their participation in forest management planing. Forest management planning is the key "stick" policy instrument of the current forest governance system in both countries, based on a top-down, hierarchically imposed and enforced set of compulsory rules on management objectives and timber harvesting. Forest management rights in private forest belong to the State/ Canton as governmental or cantonal forest authorities prepare the FMPs on the behalf of the PFOs. Therefore, as in other European countries forest authorities still keep a central role in guiding and supervising the private forest management and the forest management planning is a way to extend the central-regulatory decision-making process to the resource-unit level (Weiss et al. 2012). Consequently, PFOs have little or no power to change or influence the structure of management of their resource, as both countries have a compulsory FMP.

Significant differences exist between Slovenia and $\mathrm{FBiH}$ in terms of forest management planning system, as in Slovenia FMPs are prepared as a common plan for all forests regardless of ownership, while in $\mathrm{FBiH}$ there are two parallel forest management and planning systems (one for state forests and one for private forests). From the analysis it is evident that more importance is given to public forests compared to private forests in $\mathrm{FBiH}$, considering that FMPs for state forests require the approval of the ministry responsible for forestry and an opinion from the local community. It remains unclear who (if anyone?) approves a FMPs for private forests prepared by the Cantonal Ministry. Does this mean that private forests are only of importance at the cantonal level and that the Federal/State level has no interest in how this resource is managed as a public good? Nor is the opinion of the local community required, even though the negative consequences of incorrectly applied management measures (regardless of forest ownership), first become apparent at the local level (i.e. water supply interruption, landslides, torrents, climate changes, etc.). Based on that it is necessary to ensure the equal status of all forest in $\mathrm{FBiH}$, regardless of ownership, with adequate forest policy measures and legal solutions as it is a case in Slovenian and most of the European countries (Brukas \& Sallnäs 2012; Bouriaud et al. 2013; Nichiforel et al. 2018).

\subsection{Private forest owners' participation in forest management planning - main failure of effective law enforcement}

Large disparities also exist between Slovenia and $\mathrm{FBiH}$ in the area of PFOs participation in forest management planning procedures. The PFOs participation in the forest management planning processes is prescribed in Slovenia, but their capability to determine the management objectives is limited compared to other European countries (especially Nordic and Central-West ones, where active involvement of PFOs in setting the management objectives within the limits of the law is prescribed) (Brukas \& Sallnäs 2012; Nichiforel et al. 2018), as formal consultation with PFOs along the planning process is planned, but their interest are not necessarily included in FMPs. In contrary, interests of PFOs in $\mathrm{FBiH}$ are not considered at all in forest management planning processes. In practice this means that the participation of PFOs is not considered in the forest management planning process. They also do not know what is planned in 
these documents as a set of management measures for a 10 -year period. For this reason, in $\mathrm{FBiH}$ the provisions of the FMPs are not adhered, therefore the degradation of private forests continues. Consequently, all actors lose, the PFOs who often prioritise their own short-term economic interests due to unfavourable social conditions as well as the entire society in terms of the permanent loss of a public good (ecosystem services from the private forests). Other studies in Central and Eastern European countries also found out that a paternalistic state paradigm dominates the governance of the private forests and that the participatory mechanisms are rather absent (Dragoi et al.2011; Bouriaud et al. 2013). In such circumstances, FMPs in both countries function as a "stick" and not as a "sermons", guiding and encouraging PFOs to pursue forest management practices that are perceived to be desirable. Indeed as evident from other research (Brukas\&Sallnäs 2012), forest management planning has vast potential for the provision of individualised advice, through direct interactions between PFOs and planners who have thorough knowledge about the PFOs' properties and are tasked with balancing policy objectives against PFOs' needs.

\subsection{Private forest owners' cooperation as the main supporting policy instrument for the implementation of the regulatory framework}

In order to improve the social and economic position of PFOs, voluntary bottom-up cooperation through interest associations emerged in both countries (Glück et al. 2010; Pezdevšek Malovrh et al. 2011). The potentials of voluntary cooperation in interest associations has not yet been properly recognised by $\mathrm{PFO}$ in $\mathrm{FBiH}$, therefore the experience with it is modest (Glück et al. 2010). The situation is different in Slovenia, where PFOs are organised in interest associations at the local level (Pezdevšek Malovrh 2010; Pezdevšek Malovrh et al. 2010; Aurenhammer et al. 2017; Pezdevšek Malovrh\&Laktić 2017; Plevnik\&Pezdevšek Malovrh 2021) and in the Forest Owners' Association of Slovenia at the state level (Mori et al. 2006; Plevnik\&Pezdevšek Malovrh 2021). Although there are different experiences in both countries related to PFOs voluntary interest cooperation, the cooperation is recognized by the government as a supportive forest policy instrument. Therefore, establishment and management of their interest association is prescribed by legislation, but significant differences between the jurisdictions exists. For example, CBC Forest Law only stipulates that PFOs may establish a PFOA for the purpose of exercising their property rights, while Slovenian Forest Law has a separate chapter on cooperation that encourages cooperation in different organisational forms among PFOs to increase the efficiency of forest management and marketing of forest products and forest biomass, and also provides initial financial incentives. In this specific case i.e., where the $\mathrm{CBC}$ Forest Law is in question, the mentioned provision itself is controversial, as it only serves to open the possibility of voluntary establishment of PFOA, which is already guaranteed to all citizens through the other legislation (Law on Associations and Foundations). If there was a real intent to support activities for the establishment of PFOA via this Law, as a necessary link between the PFOA members and the forest authorities, then it would be necessary to regulate the key actors and their role, conditions (i.e. number of members, necessary management area, level of activity, etc.), time period (initial or continuous support), activities (silviculture, protection, exploitation, timber sale, biomass production for energy, ecotourism, etc.), and financial sources from which the formation of these PFOA would be supported, as it is regulated in Slovenian Forest Law. Furthermore, within the framework of the "Smart-regulation" principles (Gunningham\&Grabosky 1999; Van Gossum et al. 2012), it would be useful in both countries to define a specific mix of supportive forest policy instruments for different groups of PFOs (large vs. small, active vs. passive, etc.) and consider options for mandatory membership in PFOA for large and market-oriented PFOs as well as potentials for long-term business cooperation between PFOs and entrepreneurs (or PFOA) in the form of forest leasing or forest management agreement, as is already the practice in Scandinavian countries (Kurttila et al. 2016; Staal Wästerlund\&Kronholm 2017; Laakkonen et al. 2019) and has been assessed in Slovenia (Iveta 2017; Kurttila et al. 2017; Iveta\&Pezdevšek Malovrh 2021). Such an approach would have a positive impact on the formation of PFOA, which on the one hand, would set up themselves as legitimate representatives of the interests of their members (PFOs) and, on the other hand would become a partner of the public forest administration in the creation of a participatory and transparent forest policy, as is the case in many developed European countries (Fabra-Crespo\&Rojas-Briales 2015; Section 2020).

\section{Conclusions}

Public and private forests in Slovenia and FBiH differ in several aspects (i.e. growing stock, increment, type of forests) mainly due to the fact that large proportion of PFOs are passive and lacks knowledge of both forest management and the related bureaucratic procedures. Therefore, our study assesses how the regulatory framework affects PFOs' rights, forest management and accelerates cooperation of PFOs. The results showed that forest legislation and institutional arrangements in $\mathrm{FBiH}$ do not recognise private forests as equally important as public forests, which is not the case in Slovenia where private forest ownership predominate. Anyhow, PFOs in both countries suffer from a restrictive and prescriptive regulatory framework regarding private forests. 
The state-lead approach to the private forest management has serious implications not only on the economic content of PFOs property rights, but also on the learning and adaptive capacity of private forestry to cope with current challenges such as climate change, increased demand from outside the forest sector, or the marketing of ecosystem services. Moreover, little or no attention has been given to the scale of private forest properties or PFOs needs and capacities. The focus of current forest policy is to prevent undesirable management practises. Therefore, FMPs play an important regulatory role as a kind of precautionary leverage and serve as effective control, but with several deficiencies, especially excessive administrative and bureaucratic costs and a favourable basis for corruption and illegality. Such a forest policy system based on a strong regulation struggles with an enforcement problem (de jure vs. de facto). Therefore, deregulation of forest policy is necessary to liberalise the decision-making freedom of PFOs. This implies a shift from command-and-control approaches to marked based, self-regulatory and voluntary measures. The deregulation of forest policy, in particular forest management and property rights, confirms the proliferation of an approach based on soft laws where policy decision makers are expected to guide forest policy through a new set of policy instruments, mainly economic and informational one. By doing so, active involvement of private forestry sector in forest policy making processes is expected and will increase legitimacy of agreed decisions and lead to more plural and democratically-oriented forestry sectorthe key preconditions for further development of national forest policies.

\section{Acknowledgement}

This research was funded by the Federal Ministry of Education and Science of the Federation of Bosnia and Herzegovina and Slovenian Research Agency, grant number No. BI/BA/21-23020 through the project "Research on possibilities for business cooperation between private forest owners towards sustainable management and improvement of environment conditions in Slovenia and Bosnia and Herzegovina”.

\section{References}

Adam, F.,Makarovič, M., 2001: Tranzicijske spremembe v luči družboslovnih analiz. Teorija in praksa, 38:373-385.

Aurenhammer, P. K., Ščap, Š., Triplat, M., Krajnc, N., Breznikar, A., 2017: Actors' Potential for Change in Slovenian Forest Owner Associations. Small-scale Forestry, 17:165-189.

Avdibegović, M., Nonić, D., Posavec, S., Petrović, N., Marić, B., Milijić, V. et al., 2010a: Policy Options for Private Forest Owners in Western Balkans: A Qualitative Study. Notulae Botanicae Horti Agrobotanici Cluj-Napoca, 38:257-261.
Avdibegović, M., Petrović, N., D., N., Marić, B.,Posavec, S., 2010b: Spremnost privatnih šumoposjednika u Hrvatskoj, Srbiji i Bosni i Hercegovini na suradnju pri izgradnji i održavanju šumskih cesta. Šumarski list, 134:55-63.

Bouriaud, L., Nichiforel, L., Weiss, G., Bajraktari, A., Curovic, M., Dobsinska, Z. et al., 2013: Governance of private forests in Eastern and Central Europe: An analysis of forest harvesting and management rights. Annals of Forest Science, 56:199-215.

Brukas, V., Sallnäs, O., 2012: Forest management plan as a policy instrument: Carrot, stick or sermon? Land Use Policy, 29:605-613.

Côté, M.-A., Généreux-Tremblay, A., Gilbert, D., Gélinas, N., 2017: Comparing the profiles, objectives and behaviours of new and longstanding non-industrial private forest owners in Quebec, Canada. Forest Policy and Economics, 78:116-121.

Čabaravdić, A., Avdibegović, M., Delić, S., Kadrić, N., Marić, B.,Pezdevšek Malovrh, Š., 2011: Classification of private forest owners in Bosnia-Herzegovina based on different clustering techniques. Radovi Šumarskog fakulteta Sarajevo, 2:45-58.

Černač, G.,Pezdevšek Malovrh, Š., 2020: Analiza uspešnosti prodaje gozdnih lesnih sortimentov v gozdarski zadrugi lastnikov gozdov Pohorje-Kozjak $=$ Analysis of the effectiveness of forest wood products sales in the Pohorje - Kozjak private forest owner cooperative. Acta Silvae et Ligni, 122:1-17.

Dayer, A. A., Allred, S. B.,Stedman, R. C., 2014: Comparative Analysis and Assessment of Forest Landowner Typologies. Society \& Natural Resources, 27:1200-1212.

Dragoi, M., Popa, B.,Blujdea, V., 2011: Improving communication among stakeholders through ex-post transactional analysis - case study on Romanian forestry. Forest Policy and Economics, 13:16-23.

Fabra-Crespo, M., Rojas-Briales, E., 2015: Comparative analysis on the communication strategies of the forest owners' associations in Europe. Forest Policy and Economics, 50:20-30.

Feliciano, D., Bouriaud, L., Brahic, E., Deuffic, P., Dobsinska, Z., Jarsky, V. et al., 2017: Understanding private forest owners' conceptualisation of forest management: Evidence from a survey in seven European countries. Journal of Rural Studies, 54:162-176.

Ferlin, F., Herbst, P., Golob, A.,Kamper, P., 2010: Expert experiences in development of recent forest legislation of selected countries of the West Balkan. In: R. Šulek, P., Herbst, F., Schmithüsen (eds.): Legal Aspects of European Forest Sustainable Development. Technical University in Zvolen, p. 7-24.

Ficko, A., 2019: Private Forest Owners' Social Economic Profiles Weakly Influence Forest Management Conceptualizations. Forests, 10:956.

Ficko, A., Bončina, A., 2013: Probabilistic typology of management decision making in private forest properties. Forest Policy and Economics, 27:34-43. 
Ficko, A., Lidestav, G., Ní Dhubháin, Á., Karppinen, H., Zivojinovic, I.,Westin, K., 2019: European private forest owner typologies: A review of methods and use. Forest Policy and Economics, 99:21-31.

Glück, P., 2000: Policy means for ensuring the full value of forests to society. Land Use Policy, 17:177-185.

Glück, P., Avdibegović, M., Čabaravdić, A., Nonić, D., Petrović, N., Posavec, S. et al., 2010: The preconditions for the formation of private forest owners' interest associations in the Western Balkan Region. Forest Policy and Economics, 12:250-263.

Glück, P., Avdibegović, M., Čabaravdić, A., Nonić, D., Petrović, N., Posavec, S. et al., 2011: Private forest owners in the Western Balkans - Ready for the formation of interest associations. EFI Research Report 25. Joensuu, Finland, European Forest Institute, 234 p.

Golubović, Z. T., 1995: Social change in 1990's and social character: The case of Yugoslavia. Sociologija, 37:441-453.

Gunningham, N.,Grabosky, P., 1999: Smart regulation. Designing Environmental Policy. Oxford Legal Studies. New York, Oxford University Press, 494 p.

Iveta, N., 2017: Ocena pripravljenosti zasebnih lastnikov gozdov za poslovno sodelovanje pri gospodarjenju z gozdom na primeru revirja Vodice. Biotehniška fakulteta, Magistersko delo (magisterski študij - 2. stopnja). Ljubljana, Univerza v Ljubljani, 137 p.

Iveta, N.,Pezdevšek Malovrh, Š., 2021:Aktiviranje gospodarjenja vzasebnih gozdovih s pomočjo poslovnega sodelovanja med zasebnimi lastniki gozdov in ponudniki gozdarskih storitev: študij primera revir Vodice Acta Silvae et Ligni, (in press).

Kumer, P., 2017: The Role of Socio-Geographic Factors in Managing Private Small-Scale Forest Estates. Department of Geography, Doctoral thesis. Ljubljana, University of Ljubljana, 134 p.

Kumer, P.,Potočnik Slavič, I., 2016: Heterogeneous small-scale forest ownership : complexity of management and conflicts of interest. Revue belge de geographie, 4:1-21.

Kumer, P., Štrumbelj, E., 2017: Clustering-based typology and analysis of private small-scale forest owners in Slovenia. Forest Policy and Economics, 80:116124.

Kurttila, M., Hujala, T., Hänninen, H., Kumela, H., 2016. Family forest owners' opinion on potential forest leasing service in Finland. In: G. Weiss et al. (eds.): Forest ownership changes in Europe: trends, issues and needs for action. Final conference of the COST Action FP1201 FACESMAP, Vienna, Austria.

Kurttila, M., Hujala, T., Pykäläinen, J., 2017. Forest leasing service potential in Slovenia - a feasibility study, $6 \mathrm{p}$.

Laakkonen, A., Hujala, T., Pykäläinen, J., 2019: Integrating intangible resources enables creating new types of forest services - developing forest leasing value network in Finland. Forest Policy and Economics, 99:157-168.
Leban, V., 2014: Efficiency analysis of forest owners associations in Slovenia and Germany, M.Sc. thesis. Ljubljana, University of Ljubljana, Biotechnical Facutly, Department of Forestry and Renewable Forest Resources, $165 \mathrm{p}$.

Leban, V., Pezdevšek Malovrh, Š., Zadnik Stirn, L.,Krč, J., 2016: Forest biomass for energy in multi-functional forest management: Insight into the perceptions of forest-related professionals. Forest Policy and Economics, p. 87-93.

Marković, J., Jovančićević, B.,Avdibegović, M., 2008: Support of the State Forest Service to private forest ownership - comparative analysis in Serbia and Slovenia. Works of the Faculty of Forestry, p. 47-59.

Mori, J., Kotnik, I., Lesnik, T., 2006: Možnost sodelovanja Zavoda za gozdove Slovenije, Kmetijsko gozdarske zbornice Slovenije in Zveze lastnikov gozdov Slovenije za razvoj povezovanja lastnikov gozdov. Gozdarski vestnik, 64:476-502.

Nichiforel, L., Deuffic, P., Thorsen, B.J., Weiss, G., Hujala, T., Keary, K. et al., 2020: Two decades of forest-related legislation changes in European countries analysed from a property rights perspective. Forest Policy and Economics, 115:102146.

Nichiforel, L., Keary, K., Deuffic, P., Weiss, G., Thorsen, B.J., Winkel, G. et al., 2018: How private are Europe's private forests? A comparative property rights analysis. Land Use Policy, 76:535-552.

Nichiforel, L.,Schanz, H., 2011: Property rights distribution and entrepreneurial rent-seeking in Romanian forestry: a perspective of private forest owners. Eur J Forest Res, 130:369-381.

Nikolić, V., A., R., Petrović, N., Marić, B., Bećirović, D., Pezdevšek Malovrh, Š. et al., 2011: Forest Law regulations on private forests in Serbia, the Federation of Bosnia-Herzegovina and Macedonia. In: R. Deltuvas, P. Herbst, G. Činga (eds.): Legal Aspects of European Forest Sustainable Development. Aleksandras Stulginskis University, Kaunas, Lithuania, p. 166-176.

Nonić, D., Tomić, N., Marković, J., Herbst, P., Krajčič, D., 2006: Organization of private forest owners in Serbia compared to Austria, Slovenia and other Central European countries: Building the European Commons: From Open Fields to Open Source, European Regional Meeting of the International Association for the Study of Common Property (IASCP), Brescia, Italy, $14 \mathrm{p}$.

Pezdevšek Malovrh, Š., 2010: Influence of institutions and forms of cooperation on private forest management, PhD. Ljubljana, University of Ljubljana, Biotechnical Faculty, Department of Forestry and Renewable Forest Resources, 240 p.

Pezdevšek Malovrh, Š., Hodges, D.G., Marić, B.,Avdibegović, M., 2011: Private forest owners expectations of interest associations: comparative analysis between Slovenia and Bosnia-Herzegovina. Šumarski list, CXXXV:1-10. 
Pezdevšek Malovrh, Š., Kumer, P., Glavonjić, P., Nonić, D., Nedeljković, J., Kisin, B. et al., 2017: Different organizational models of private forest owners as a possibility to increase wood mobilization in Slovenia and Serbia. Croatian journal of forest engineering: [journal for theory and application of forestry engineering], 38:127-140.

Pezdevšek Malovrh, Š., Kurttila, M., Hujala, T., Kärkkäinen, L., Leban, V., Lindstad, B. H. et al., 2016: Decision support framework for evaluating the operational environment of forest bioenergy production and use: Case of four European countries. Journal of Environmental Management, 180:68-81.

Pezdevšek Malovrh, Š., Laktić, T., 2017: Poslovno povezovanje lastnikov gozdov na primeru Društva lastnikov gozdov Pohorje-Kozjak. Acta Silvae et Ligni, 113:1-13.

Pezdevšek Malovrh, Š., Nonić, D., Glavonjić, P., Nedeljković, J., Avdibegović, M.,Krč, J., 2015: Private Forest Owner Typologies in Slovenia and Serbia: Targeting Private Forest Owner Groups for Policy Implementation. Small-scale Forestry, 14:423-440.

Pezdevšek Malovrh, Š., Paletto, A., Posavec, S., Dobšinská, Z., Đorđević, I., Marić, B. et al., 2019: Evaluation of the Operational Environment Factors of Nature Conservation Policy Implementation: Cases of Selected EU and Non-EU Countries. Forests, 10:1099.

Pezdevšek Malovrh, Š., Zadnik Stirn, L., Krč, J., 2010: Influence of property and ownership conditions on willingness to cooperate. Šumarski list, 3-4:139_ 149.

Plevnik, K.,Pezdevšek Malovrh, Š., 2021: Analiza delovanja Zveze lastnikov gozdov v Slovenije s ciljem njenega izboljšanja - ali obstajajo možnosti za vzpostavitev novih poslovnih modelov sodelovanja s člani? Acta Silvae et Ligni, 124:13-28.

Poje, A., Pezdevšek Malovrh, Š., Krč, J., 2016: Factors Affecting Harvesting Intensity in Small-Scale Private Forests in Slovenia. Small-scale Forestry, 15:73-91.

Schlager, E., Ostrom, E., 1992: Property-Rights Regimes and Natural Resources: A Conceptual Analysis. Land Economics, 68:249-262.

Scriban, R. E., Nichiforel, L., Bouriaud, L. G., Barnoaiea, I., Cosofret, V.C., Barbu, C. O., 2019: Governance of the forest restitution process in Romania:An application of the DPSIR model. Forest Policy and Economics, 99:59-67.

Staal Wästerlund, D., Kronholm, T., 2017: Family Forest Owners' Commitment to Service Providers and the Effect of Association Membership on Loyalty. Smallscale Forestry, 16:275-293.

Stare, D., Grošelj, P., Pezdevšek Malovrh, Š., 2020: Ovire in rešitve pri sanaciji v ujmah poškodovanih zasebnih gozdov $=$ Barriers and solutions in salvage logging in private forests damaged by natural disasters. Acta Silvae et Ligni, 123:13-30.
Van Gossum, P., Arts, B.,Verheyen, K., 2012: "Smart regulation": Can policy instrument design solve forest policy aims of expansion and sustainability in Flanders and the Netherlands? Forest Policy and Economics, 16:23-34.

Vuletić, D., Potočić, N., Krajter, S., Seletković, I., Fürst, C., Makeschin, F. et al., 2010: How Socio-Economic Conditions Influence Forest Policy Development in Central and South-East Europe. Environmental Management, 46:931-940.

Weiss, G., Gudurić, I.,Wolfslehner, B., 2012. Review of forest owners' organizations in selected Eastern European countries, Rome. 57

Weiss, G., Lawrence, A., Hujala, T., Lidestav, G., Nichiforel, L., Nybakk, E. et al., 2019: Forest ownership changes in Europe: State of knowledge and conceptual foundations. Forest Policy and Economics, 99:9-20.

Winkel, G., 2017: Towards a sustainable European forest-based bioeconomy - assessment and the way forward. What Science Can Tell Us 8, European Forest Institute, $162 \mathrm{p}$.

Winkel, G., Gleißner, J., Pistorius, T., Sotirov, M.,Storch, S., 2011: The sustainably managed forest heats up: discursive struggles over forest management and climate change in Germany. Critical Policy Studies, 5:361-390.

Winkler, I., Medved, M., 1994: Spremembe lastninske strukture gozdov zaradi denacionalizacije in njihove gozdnogospodarske posledice. Zbornik gozdarstva in lesarstva, 44:215-246.

Wolfslehner, B., Avdibegović, M., 2015: Analysis of the Forest Sector in Bosnia and Herzegovina - Preparation of IPARD Forest and Fisheries Sector Reviews in Bosnia and Herzegovina. Budapest, Hungary, FAO Regional Office for Europe and Central Asia, 153 p.

Ziegenspeck, S., Härdter, U.,Schraml, U., 2004: Lifestyles of private forest owners as an indication of social change. Forest Policy and Economics, 6:447458.

\section{Other sources}

Section, U.F.F.a.T., 2020: Who owns our forests? Forest ownership in the ECE region. Geneva, Switzerland, United Nations Economic Commission for Europe, $198 \mathrm{p}$.

UN, 2011. The European Forest Sector Outlook Study II. 2010-2030, Geneva. 111

ZGS, 2020: Report of Slovenian Forest Service about forests for 20119. Ljubljana, Zavod za gozdove Slovenije, $135 \mathrm{p}$. 


\section{Appendix}

Table 1. Summary results of PRIF indicators in FBiH and Slovenia.

\begin{tabular}{|c|c|c|}
\hline \multirow{2}{*}{ PRIF indicators } & \multicolumn{2}{|c|}{ Country } \\
\hline & $\mathrm{FBiH}$ & Slovenia \\
\hline \multicolumn{3}{|l|}{ Access right } \\
\hline Freedom of PFOs to enter their own forests & $\begin{array}{l}\text { Right is fully granted to the PFOs, restrictions may } \\
\text { apply, restrictions are compensated }\end{array}$ & $\begin{array}{l}\text { Right is fully granted to the PFOs, restrictions may } \\
\text { apply, restrictions are compensated }\end{array}$ \\
\hline \multicolumn{3}{|l|}{ Withdrawal right } \\
\hline $\begin{array}{l}\text { Freedom of PFOS to decide the amount of timber to be } \\
\text { harvested }\end{array}$ & $\begin{array}{l}\text { The amount to be harvested is entirely the result of } \\
\text { forests management planning }\end{array}$ & $\begin{array}{l}\text { The amount to be harvested is entirely the result of } \\
\text { forests management planning }\end{array}$ \\
\hline Approval needed by PFOs for timber harvesting & $\begin{array}{l}\text { Need to ask the authority for approval in any situation } \\
\text { and to adhere to the conditions of approval }\end{array}$ & $\begin{array}{l}\text { Need to ask the authority for approval in any situation } \\
\text { and to adhere to the conditions of approval }\end{array}$ \\
\hline Freedom of PFOs to perform the harvesting of trees & $\begin{array}{l}\text { PFOs is obliged to contract a person qualified and } \\
\text { trained to perform forest activities }\end{array}$ & $\begin{array}{l}\text { PFOs have the right to harvest the trees by him/herself } \\
\text { and may be assisted by their legal heirs, spouses and } \\
\text { other natural persons in the form of mutual assistance }\end{array}$ \\
\hline Freedom of PFOs to collect NWFP for personal use & $\begin{array}{l}\text { PFOs can collect a certain amount of NWFP provided in } \\
\text { the legislation without any approval or planning }\end{array}$ & $\begin{array}{l}\text { PFOs can collect a certain amount of NWFP provided in } \\
\text { the legislation without any approval or planning }\end{array}$ \\
\hline \multicolumn{3}{|c|}{ 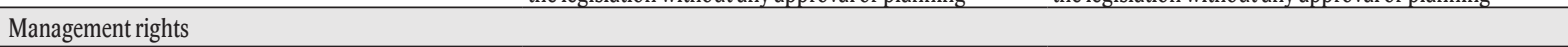 } \\
\hline Obligation of PFOs to have a forest management plan & $\begin{array}{l}\text { FMPs are mandatory, regardless of the size of the private } \\
\text { forest property and regardless of the forestry work } \\
\text { intended by the PFOs. Forest management plans for } \\
\text { private forests are financed by public authorities }\end{array}$ & $\begin{array}{l}\text { FMPs are mandatory, regardless of the size of the private } \\
\text { forest property and regardless of the forestry work } \\
\text { intended by the PFOs. Forest management plans for } \\
\text { private forests are financed by public authorities }\end{array}$ \\
\hline $\begin{array}{l}\text { Freedom of PFOs to choose forest management objec- } \\
\text { tives }\end{array}$ & $\begin{array}{l}\text { PFOs interest are not considered at all in the planning } \\
\text { process }\end{array}$ & $\begin{array}{l}\text { PFOs can bring their forest management objectives in } \\
\text { the planning process, but they have not the freedom of } \\
\text { decision }\end{array}$ \\
\hline Freedom of PFOs to select the trees to harvest & $\begin{array}{l}\text { Trees can only be felled after they have been selected, } \\
\text { marked and recorded in accordance with the forest } \\
\text { management plan An authority has to do the selection of } \\
\text { trees and PFOs have to pay }\end{array}$ & $\begin{array}{l}\text { Trees can only be felled after they have been selected, } \\
\text { marked and recorded in accordance with the forest } \\
\text { management plan. An authority has to do the selection } \\
\text { of trees free of charge }\end{array}$ \\
\hline \multicolumn{3}{|c|}{ col } \\
\hline $\begin{array}{l}\text { Freedom of PFOs to restrict the public access to their } \\
\text { property }\end{array}$ & $\begin{array}{l}\text { Free access in private forest cannot be restricted by } \\
\text { PFOs because it is everyone's right }\end{array}$ & $\begin{array}{l}\text { Free access in private forest cannot be restricted by } \\
\text { PFOs because it is everyone's right }\end{array}$ \\
\hline $\begin{array}{l}\text { Freedom of PFOs to restrict the collection of NWFPs on } \\
\text { their property, }\end{array}$ & $\begin{array}{l}\text { PFOs must allow recreational collection of NWFP in } \\
\text { their forest in accordance with the regulations; maxi- } \\
\text { mum quantity limits apply }\end{array}$ & $\begin{array}{l}\text { PFOs must allow recreational collection of NWFP in } \\
\text { their forest in accordance with the regulations; maxi- } \\
\text { mum quantity limits apply. } \\
\text { PFOs can partly restrict the collection }\end{array}$ \\
\hline $\begin{array}{l}\text { Freedom of PFOs to decide who may hunt on their } \\
\text { property }\end{array}$ & $\begin{array}{l}\text { PFOs can solely decide who is allow to hunt in their } \\
\text { forests - permission of PFOs are needed }\end{array}$ & $\begin{array}{l}\text { PFOs has to accept hunting activities that take place in } \\
\text { their forest and are not compensated for this }\end{array}$ \\
\hline \multicolumn{3}{|l|}{ Alienation right } \\
\hline $\begin{array}{l}\text { Freedom of PFOs to decide to whom to sell the forest } \\
\text { land }\end{array}$ & PFOs can freely decide to whom to sell the forest land & $\begin{array}{l}\text { A pre-emption right is always applied in favour of the } \\
\text { state/local communities and neighbouring owners }\end{array}$ \\
\hline Freedom of PFOs to decide to whom to sell the timber & $\begin{array}{l}\text { The right of PFOs to sell timber is altered by a specific } \\
\text { procedure. No restrictions imposed on the PFOs in } \\
\text { setting the price nor the selling method or buyer }\end{array}$ & $\begin{array}{l}\text { The right of PFOs to sell timber is altered by a specific } \\
\text { procedure. No restrictions imposed on the PFOs in } \\
\text { setting the price nor the selling method or buyer }\end{array}$ \\
\hline
\end{tabular}

